2009

\title{
All the More Reason for QR across the Curriculum
}

Bernard L. Madison

University of Arkansas, bmadison@uark.edu

Follow this and additional works at: https://digitalcommons.usf.edu/numeracy

Part of the Mathematics Commons, and the Science and Mathematics Education Commons

\section{Recommended Citation}

Madison, Bernard L.. "All the More Reason for QR across the Curriculum." Numeracy 2, Iss. 1 (2009):

Article 1. DOI: http://dx.doi.org/10.5038/1936-4660.2.1.1 


\section{All the More Reason for QR across the Curriculum}

\section{Keywords}

numeracy, education, quantitative reasoning, mathematics, enrollments, science, engineering

Creative Commons License

(c) (i) (9)

This work is licensed under a Creative Commons Attribution-Noncommercial 4.0 License 


\section{GUEST EDITORIAL}

\section{All the More Reason for QR across the Curriculum}

The quantitative reasoning burden on US residents is huge and growing. In fact, no society has ever imposed such a heavy quantitative reasoning (QR) burden on its members; the consequences of this imposition are not at all clear and could result in the undoing of democratic processes. This undoing is much more likely because there has been no effective educational response to the increasing QR burden. An effective response will require a significant change in K-12 education plus all the collegiate disciplines working in concert. Some symptoms of the lack of a response follow along with some indications that make an effective response more challenging.

\section{QR Education Challenges in K-12}

Rightly or wrongly, QR education in K-12 schools is the province of the mathematics curriculum, usually including data analysis, probability and statistics. Early-grades mathematics is very contextual, the correct mode for QR education. However, through middle school and into high school, mathematics becomes far less contextual and more algorithmic, not the correct mode for QR education. And the elephant in today's mathematics classroom is standardized accountability testing, which, from all indications, does not promote QR. How extensive is such testing? From grade 8 to grade 12, many students sit for 6-8 standardized mathematics tests, some with high stakes for the schools or students. Many of the items on these tests are narrow and assess methodological skills. Quite understandably, teachers drill students for such items. Following these K12 tests, many colleges administer mathematics placement tests that reinforce the importance of narrow algebraic manipulation skills.

\section{QR Education Challenges in College}

These circumstances in $\mathrm{K}-12$ leave much of QR education to colleges, where it falls largely to the general education core and, again, rightly or wrongly, QR education is often considered the sole province of mathematics and statistics. (Fortunately, this is changing in some places where QR education is being accepted as a curriculum-wide obligation.) College mathematics enrollments indicate that this QR education is falling far short of what is needed. There are no large enrollment general education mathematics courses that are QR-friendly. The 
largest enrollment college mathematics courses are courses in traditional algebra (not QR-friendly), and the low levels of the mathematics enrollments are not encouraging. In Table 1, I list fall semester college mathematics enrollments from the 2005 survey of the Conference Board of the Mathematical Sciences ${ }^{1}$ (Lutzer et al. 2007). The CBMS Survey has been conducted every five years since 1965, so I include enrollment data for both 1995 and 2005 to show some changes that are also not encouraging.

\section{Table 1. Enrollments in Mathematics Courses at U.S. Two-Year Colleges and Four-Year Colleges and Universities ${ }^{2}$ (Lutzer et al. 2007)}

\begin{tabular}{|l|c|c|c|c|}
\hline \multicolumn{1}{|c|}{$\begin{array}{c}\text { Level of } \\
\text { courses }\end{array}$} & $\begin{array}{c}1995 \text { Fall } \\
\text { Enrollment }\end{array}$ & $\begin{array}{c}2005 \text { Fall } \\
\text { Enrollment }\end{array}$ & $\begin{array}{c}1995 \\
\text { percent at level }\end{array}$ & $\begin{array}{c}2005 \\
\text { percent at level }\end{array}$ \\
\hline $\begin{array}{l}\text { Pre-college } \\
\text { (remedial) }\end{array}$ & 985,000 & $1,166,000$ & $35 \%$ & $37 \%$ \\
\hline $\begin{array}{l}\text { Introductory } \\
\text { (pre- } \\
\text { calculus) }\end{array}$ & 908,000 & $1,027,000$ & $32 \%$ & $32 \%$ \\
\hline $\begin{array}{l}\text { Calculus } \\
\text { plus } \\
\text { advanced }\end{array}$ & 763,000 & 807,000 & $27 \%$ & $25 \%$ \\
\hline
\end{tabular}

There are some QR-encouraging signs in the data: (1) lower-level statistics fall enrollments ${ }^{3}$ increased from 236,000 in 1995 to 319,000 in 2005, and (2) enrollments increased in possibly QR-friendly mathematics courses such as mathematics for the liberal arts (74,000 in 1995 to 123,000 in 2005) and modeling-based college algebra courses.

College mathematics enrollments, although generally increasing, have lagged behind overall college enrollments. From 1995 to 2005 total undergraduate enrollment increased by $22 \%$ from $12,232,000$ to $14,954,000$ (Planty et al., 2008) while fall semester mathematics enrollments increased by $12 \%$ from 3,013,000 to 3,374,000. In 1995 there was one fall semester college mathematics enrollment for each 3.97 college students, and this was approximately the same in two-year

\footnotetext{
${ }^{1}$ http://www.cbmsweb.org/ (accessed 12/31/08)

${ }^{2}$ About $5 \%$ of the enrollments are in "other" courses (at two-year colleges) that do not fit any of the levels.

${ }^{3}$ These enrollments were in mathematics departments and statistics departments.
} 
or four-year institutions; by 2005 that had fallen to one enrollment for each 4.5 students, and in four-year colleges there was one enrollment for each 5.5 students.

\section{Mathematically Intensive Majors are not Keeping Pace with College Enrollments}

One of the reasons why college mathematics enrollments are not keeping pace with student enrollment is that smaller fractions of college students are choosing college majors that are traditionally mathematically intensive. Of course, those traditionally mathematically intensive majors do not necessarily produce QRliterate graduates, but they could.

The College Board's 2008 SAT survey of over a million college-bound high school seniors revealed that about $24 \%$ of them intended to major in the traditional mathematical or quantitative disciplines, down from $27 \%$ ten years earlier. A similar survey of a similarly-sized population by ACT showed a similar drop from 24\% choosing mathematical disciplines in 1998 to $21 \%$ in 2008 . Notable changes were decreases in the fraction of students choosing engineering and computer science. The fractions choosing physical sciences or biological sciences changed very little while the mathematics fraction, although less than $1 \%$, increased. Declines in these fractions are partially masked by the increasing college enrollments. One should note, however, that $1 \%$ of either of the samples (SAT and ACT) is about 10,000 students, so a 3\% drop represents 30,000 students. Since freshman enrollment now is about 3 million students, if these samples are representative, then there are about 90,000 fewer freshmen majors in mathematically intensive disciplines than would have been predicted a decade back.

\section{Possible Meanings}

Why are the shifts described above taking place, and what does it mean for numeracy education? Does it mean that mathematically intensive majors are less popular because of their quantitative nature? Surely, there are multiple reasons, but unpopularity of mathematics carries over to unpopularity of $\mathrm{QR}$ because the two are linked in the public's mind.

Perhaps the more quantitative nature of contemporary business, social sciences, or allied health professions is attracting students. This is not likely. These fields likely remain viewed as non-quantitative in $\mathrm{K}-12$ because $\mathrm{QR}$ is not across the K-12 curriculum, leaving more of the QR education burden to colleges.

Perhaps the perceived relevance by students of subjects such as psychology, business, visual or performing arts is greater than that of the sciences or technical subjects. If this is so, and my experience tells me that it is, then those of us in the 
sciences are failing to connect strongly enough what we teach to the everyday world of our students, and that does not promote QR education.

Perhaps this is just a damping of the pendulum swing from mathematically intensive disciplines to ones less so. There have been no recent stimuli for mathematics and science like the 1958 launch of Sputnik. Issues like global warming, security against terrorism and the implications for citizens' rights, and alternative energy sources would seem to have that level of national urgency, but they do not yet.

Perhaps this is just settling down to normal. But normalcy in college education is difficult to determine since the college-going rate is much higher than ever before. This, of course, should prompt changes in college general education, but in many places and many disciplines it has not.

\section{The Way Out: QR Must Be a Shared Responsibility}

Whatever the cause for the above shifts, they make quantitative reasoning across the curriculum more critical. Reduced interest in mathematically intensive disciplines is likely a symptom of attitude shifts. If that reduced interest means that students are less quantitatively inclined, then that adds to the QR education problem, but does not diminish the QR burden on college students in their nonmathematically intensive majors or in their everyday lives as consumers and citizens of a democracy. These circumstances do mean that $\mathrm{QR}$ educationabsolutely necessary if we are to sustain our democratic processes-cannot be the sole province of one or two disciplines. Whatever students major in, we must ensure that they learn to reason quantitatively in their contemporary world.

BERNARD L. MADISON

\section{References}

Lutzer, D., S. Rodi, E. Kirkman, and J. Maxwell. 2007. CBMS 2005: Statistical Abstract of Undergraduate Programs in the Mathematical Sciences in the United States. Providence, RI: American Mathematical Society. Available at http://www.ams.org/cbms/cbms2005.html (accessed 12/31/08).

Madison, B.L. 2004. Two mathematics: Ever the twain shall meet? Peer Review, $6(4), 9-12$.

Planty, M., W. Hussar, T. Snyder, S. Provasnik, G. Kena, R. Dinkes, A. KewalRamani, and J. Kemp. 2008. The Condition of Education 2008 (NCES 2008-031). National Center for Education Statistics, Institute of Education Sciences. Washington, DC: U.S. Department of Education. 